\title{
German Participle II Constructions as Adjuncts*
}

\author{
Ilse Zimmermann \\ Potsdam
}

\begin{abstract}
The present investigation is concerned with German participles II (past participles) as lexical heads of adjuncts.

Within a minimalist framework of sound-meaning correlation, the analysis presupposes a lexicalist conception of morphology and the differentiation of Semantic Form and Conceptual Structure. It is argued that participles II have the same argument structure as the underlying verbs and can undergo passivization, perfectivization and conversion to adjectives. As for the potential of participles to function as modifiers, it is shown that attributive and adverbial participle constructions involve further operations of conversion. Participle constructions are considered as reduced sentences. They do not have a syntactic position for the subject, for an operator (comparable to the relative pronoun in relative clauses) or for an adverbial relator (as in adverbial clauses). The pertinent components are present only in the semantic structure.

Two templates serve the composition of modifiers - including participle constructions with the modificandum. It is necessary to differentiate between modification which unifies two predicates relating to participants or to situations and frame setting modification where the modifier is given the status of a propositional operator.

The proposed analysis shows that the high degree of semantic underspecification and interpretative flexibility of German participle II constructions resides in the indeterminacy of participles II with respect to voice and perfect, in the absence of certain constituents in the syntactic structure and in the presence of corresponding parameters in the Semantic Form of the participle phrases.
\end{abstract}

\section{Introduction}

This article refers to work I did on the syntax and semantics of constructions with an adjective or a participle as lexical head and on modification (Zimmermann 1985, 1987, 1988a, 1988b, 1992). Now I will put forward certain refinements, which partly result from the comparison of my analysis with the treatment of participle phrases by Fanselow (1986), Wunderlich (1987, 1997a), Bierwisch (1990, 1997b), Kratzer (1994a, 1994b, 1998), von Stechow (1998, 1999a, $1999 \mathrm{~b})$ and Dölling (1998). A more detailed version of this reconsideration is published in Zimmermann $(1999,2000)$.

I shall concern myself with German participles II (past participles) as lexical heads of attributive and adverbial phrases, as in (1)-(6).

(1) die in meiner Heimat gleich nach Ostern geschorenen Schafe

the in my home country right after easter shorn sheep

'the sheep that are/were shorn in my home country right after easter'

\footnotetext{
* I presented this paper in 1998 at the Zentrum für Allgemeine Sprachwissenschaft and in 1999 at the Projektgruppe Strukturelle Grammatik in Berlin, at the workshop „Kopulaverben und Prädikative“ of the SFB 282 in Wuppertal, January 15-16, 1999, at a conference in honour of Anita Steube at the Institut furr Linguistik in Leipzig, July 9, 1999 and at the conference „Approaching the Grammar of Adjuncts“ at the University of Oslo, September 22-25, 1999. I would like to thank the respective audiences for the inspiring discussions. For helping with the English text I am indepted to Jean and Barbara Jane Pheby and Ewald Lang.
} 
(2) die trotz der Kälte schon geöffneten Apfelblüten

the despite the cold already opened apple blossoms

'the apple blossoms that (have) already opened despite the cold'

(3) der seit zwei Wochen verreiste Nachbar

the since two weeks away neighbour

'the neighbour who has been away for two weeks'

(4) Irene kann sich, endlich von ihrer Angst befreit, wieder besser konzentrieren.

Irene is able, finally freed of her fear, again to concentrate better

'Finally freed of her fear, Irene is able to concentrate better.'

(5) Das Fleisch bleibt, im Römertopf gegart, schön saftig.

the meat stays, in the chicken brick roasted, nice and juicy

'Roasted in the chicken brick, the meat stays nice and juicy.'

(6) Mit ein paar Blumen geschmückt, sieht das Zimmer gleich viel freundlicher aus.

with a few flowers decorated, looks the room at once much more friendly

'Decorated with a few flowers, the room looks much more friendly at once.'

In the examples (1)-(3) we are dealing with modifiers attributively used which agree with the nominal head of the modificandum in gender, number and case. In (4)-(6) there is no morphologically indicated relation between the modifier and the modificandum. I regard these participle constructions as adverbial modifiers, which can be paraphrased as adverbial sentences. In many languages there are special morphemes marking the adverbial form of the verb, the so-called adverbial participles (Haspelmath 1995, König 1995, Hengeveld 1998, V.P. Nedjalkov 1995, I.V. Nedjalkow 1995, 1998, Růžička 1978, 1982, Kortmann 1995).

I will leave aside the characterization of participle constructions as secondary predicates.

\section{The framework}

Within a minimalist framework of sound-meaning correlation the analysis follows a lexicalist conception of morphology (Wunderlich 1997c) and the differentiation of Semantic Form and Conceptual Structure (Bierwisch 1987, 1997a, Lang 1987, 1990, 1994, Dölling 1997).

A strict distinction is made between morphological marking and semantic interpretation of morphological forms. There are syntactic configurations which serve to check morphosyntactic features and/or their semantic interpretation. This means that the relation between morphology and semantics in many cases is mediated by syntax.

The semantic characterization of constituents can be underspecified. It is assumed that

the Semantic Form of linguistic expressions involves parameters which are specified in Conceptual Structure (Dölling 1997). I will show explicitly in which respects participle II constructions are semantically underdetermined.

Any analysis of participles II must take a stand on the nature of tense, aspect and Aktionsarten.

Aktionsarten are semantic characteristics of verb phrases and depend on the semantics of the verb and of the modifiers and argument realizations.

As regards aspect, it is evident that German does not express aspect morphologically. There is no differentiation between perfective and imperfective aspects. I assume that in German, there are neither morphosyntactic features of aspect nor an aspect phrase. 
As regards perfect, I take it as a special time interval (Anagnostopoulou/Iatridou/Izvorski 1998) and will discuss whether it is necessary to assume a perfect phrase as von Stechow (1999a, 1999b) does.

The syntactic structure of participial modifiers is sentence-like. Only the highest domains of the extended projection of verbs - ForceP, MoodP and TenseP - are absent. The problem whether there is a special Participle phrase on top of the participle construction will be discussed below.

Participle constructions in the function of attributive or adverbial modifiers are - like all modifiers - syntactic adjuncts. This means that they can be embedded into the matrix construction at those places where they are given the right interpretation according to their nature and with respect to scope relations (Grundzüge 1981, Maienborn 1996, 1997, 1998, Frey/Pittner 1998, Haider/Rosengren 1998, Haider 1999).

\section{The analysis}

\subsection{Lexical representation of participles II as verb forms in the third status}

The participle II as an infinite verb form differs from the verb stem in the Phonetic Form (PF) and in the Morphosyntactic Characterization (MSC). Its Semantic Form (SF) basically is the same as the SF of the verb stem.

$$
\begin{aligned}
& \text { a. } / . . / \\
& \text { b. }+\mathrm{V}-\mathrm{N} \alpha \text { sein }+ \text { infin }+3 \mathrm{~S} \beta \text { part } \beta \mathrm{A}-\mathrm{Fl} \text { pass } \delta \text { perf } \varepsilon \text { max } \\
& (\varepsilon=-\rightarrow \beta=+, \gamma=-\rightarrow \delta=+) \\
& \text { c. } \lambda \mathrm{x}_{\mathrm{n}} \ldots \lambda \mathrm{x}_{1} \lambda \mathrm{t} \lambda \mathrm{s}\left[\left[\mathrm{Ts} \underline{\mathrm{B}}_{\text {asp }} \mathrm{t}\right] \&\left[\mathrm{~s} \operatorname{INST}\left[\ldots \mathrm{x}_{1} \ldots \mathrm{x}_{\mathrm{n}} \ldots\right]\right]\right] \\
& \left(\mathrm{T} \in\langle\alpha, \mathrm{i}\rangle, \alpha \in\{\mathrm{e}, \mathrm{i}\}, \mathrm{B}_{\text {asp }} \in\langle\mathrm{i},\langle\mathrm{i}, \mathrm{t}\rangle \text {, INST } \in\langle\mathrm{t},\langle\mathrm{e}, \mathrm{t}\rangle)\right.
\end{aligned}
$$

(7a) represents the PF of the affixation process of participle II formation, e.g. operiert, gelesen (without adjectival inflection) or operierte, gelesenem (with adjectival inflection). (As regards the representation of the affixes $-t$ and $-n$ of German participles II, see Zimmermann 1999.)

(7b) categorizes participles II as an infinite verb form (+infin), as third status ( $+3 \mathrm{~S})$ and as -part for the supinum or as +part for the participle (in the understanding of Bech 1955/1957). $\pm \mathrm{A}-\mathrm{F} 1$ is a morphological feature shared by adjectives, participles, determiners and certain numerals which can take adjectival inflection. \pm max serves to characterize the word structure level. + sein and -sein are selectional features of verbs forming the perfect with the auxiliary verb sein or haben respectively. Furthermore, I assume that the participle II is characterized by the morphosyntactic features +pass and/or +perf, which are the basis for selection by auxiliary verbs and for semantic interpretation of participle constructions ${ }^{1}$. The following table shows the possible combinations of the features \pm part, \pm pass and \pm perf.

1. As an illustration, I am adding the lexical representation of the auxiliary verb form hat ('has'):

(i) a. /hat/

$$
\begin{aligned}
& \text { b. }+\mathrm{V}-\mathrm{N} \text { +perf -pass -prät -fut -pl -1 -2 } \\
& \text { c. } \lambda \mathrm{P}[\mathrm{P}] \\
& +3 \mathrm{~S} \\
& \text {-part } \\
& \text { +perf } \\
& \text {-pass } \\
& \text {-sein }
\end{aligned}
$$




$$
\begin{array}{ccccl}
3 \mathrm{~S} & \text { part } & \text { pass } & \text { perf } \\
+ & + & + & + & \text { vom Chefarzt operiert(-) } \\
+ & - & + & + & \text { vom Chefarzt operiert worden sein } \\
+ & + & + & - & \text { gern gelesen(-) } \\
+ & - & + & - & \text { gern gelesen werden } \\
+ & + & - & + & \text { gestern verreist(-) } \\
+ & - & - & + & \text { gestern verreist sein, gearbeitet haben }
\end{array}
$$

The semantic impact of these feature combinations will be accounted for by special rules of semantic interpretation.

The SF of participles II is given in (7c). I assume that the SF of verbs and of their participles is an $x_{n}+2$-ary predicate with $\lambda x_{n} \ldots \lambda x_{1}$ as argument positions for participants and $\lambda t$ as argument position for time characterizations and $\lambda s$ as the referential argument position. I shall leave open whether it is necessary to have verb semantics associated with possible worlds (i.e. to have one further position for possible worlds). INST in (7c) reads as 'instantiates' and introduces the situation argument $s$ for all lexical verbs (Bierwisch 1987). $\underline{R}_{a s p}$ is a parametric relation between the time interval of the situation and a time interval $t . t$ can be specified by perfect, tense and modifiers.

\subsection{Passivization and perfectivization}

In the following, we must decide how to capture the semantics of passivization and of perfectivization. In principle, there are two possibilities. We could simply formulate semantic interpretation rules for the constituents bearing the features tpass and/or +perf and indicate on which level of syntactic projection the corresponding semantics comes into play. I will call this method affixless interpretation. The second possibility is connected with the idea of feature checking in a certain syntactic configuration with a phonetically empty functional head which brings in the pertinent semantics. I call this method affixal interpretation. It is evident that with the second solution the syntactic structure is less economic. Therefore, I tend to prefer the first method of semantic interpretation. In the following representations I will put the functional PF and MSC information into parentheses, thereby indicating the omission of the zero head and of its projection.

Passivization and perfectivization do not change the lexical category of the input. The two rules are mutually ordered. Like the auxiliaries in the verbal complex (for instance, gelesen worden sein), passivization - following the mirror principle - comes first.

\subsubsection{Passivization}

As examples like (1) and (6) illustrate there are attributive and adverbial participle II constructions with passive voice semantics. I assume that constituents with participles like gelesen or with the supinum gelesen in complex verb forms like gelesen wird, gelesen worden ist as lexical heads undergo the following rule of interpretation:

The auxiliary selects the third status of the supinum $(+3 S$-part) marked by the morphosyntactic features +perf -pass -sein. Following Bierwisch (1990), I assume that auxiliary verbs and their complements form verb complexes as in (ii):

(ii) [[ gelacht ] hat ] ('has laughed')

It is important to note that the auxiliary does not enrich the semantics of the participle II. I assume that the semantic interpretation of the participle II and of complex verb forms with the participle II is delayed. 
(9) Passive voice interpretation (PASS)

(a. $/ \varnothing /$ )

(b. +pass)

c. $\quad \lambda P \quad \lambda t \lambda s \quad \exists x[P \times t s]$ +pass

The only condition for the rule to apply is the presence of the morphosyntactic feature +pass in the MSC of the constituent to be given its passive voice semantics. Passive voice semantically consists in existential binding of the highest argument for participants. (For selectional restrictions see Rapp 1997. As regards passivization of verbs with three participants, see Zimmermann 1999, 2000.) The rule is not limited to word structure. It can be freely applied at the level of phrase structure. ${ }^{2}$ The same is true of perfectivization and of conversion to adjectives.

\subsubsection{Perfectivization}

Again, the rule of perfect interpretation applies to a constituent marked by a characteristic feature, in this case by tperf.

(10) Perfect interpretation rule (PERF)

(a. $/ \varnothing /)$

(b. +perf)

c. $\quad \lambda P \quad \lambda t \lambda s \quad \exists t^{\prime}\left[\left[t^{\prime} \triangleleft t\right] \&\left[P t^{\prime} s\right]\right]$

+ perf

$(\triangleleft \in<\mathrm{i},<\mathrm{i}, \gg\rangle)$

Semantically, perfectivization amounts to the temporal characterization that there is a time interval $t^{\prime}$ such that $t^{\prime}$ is before $(<) t$ or abuts $(x) t$ (von Stechow 1999a, 1999b). The question whether or not the abut relation must be restricted to constructions with the perfect supinum $(+3 \mathrm{~S}$-part) so that constructions with the perfect participle $(+3 \mathrm{~S}+$ part) will get the perfect semantics with the before-relation deserves clarification. ${ }^{3}$

\subsection{Conversion}

Whereas passive voice interpretation and perfect interpretation can be looked at as semantic rules combined with the checking of the features +pass and/or +perf, conversion of participles II to adjectives is connected with the change of the lexical feature $-\mathrm{N}$ of verbs to $+\mathrm{N}$ of adjectives. Participles II converted to adjectives combine with the copula sein, which in

2 The passive interpretation rule (9) has to interact with the integration of quantifier phrases in cases like (i).

(i) Es wurde alles kritisiert.

it was everything criticized

'Every thing was criticized.'

Es wurde über alles gelacht.

it was about everything laughed

'Everything was laughed at.'

Evidently, the possibility to get a $\exists x \forall y$ reading must be left open. One way to guarantee this consists in the application of passive interpretation after the integration of the universally quantized entity.

3 Possibly the temporal relation between $t$ ' and $t$ in the perfect interpretation rule (10) should be considered as a parameter, $\mathbf{R}_{\text {perf }}$, with the possible values $<$ and $\times$ the selection of which being determined in Conceptual Structure. 
modifier phrases as a rule remains silent. They can be prefixed by un- (Lenz 1995) and undergo synthetic comparative and superlative formation and occur in all environments of adjective phrases. I agree with Rapp $(1996,1997)$ that the so-called Zustandspassiv does not exist. Like Kratzer (1994a, 1994b, 1998), I assume that the conversion can take place at the level of word structure or of phrase structure.

(11) Conversion to adjectives (CONV)

a. $/ \varnothing /$

b. $+\mathrm{V}+\mathrm{N}$

c. $\lambda \mathrm{P} \quad \lambda \times \exists \mathrm{s}^{\prime} \exists \mathrm{s} \exists \mathrm{t}\left[\left[\mathrm{s}^{\prime} \mathrm{RESULT} \mathrm{s}\right] \&[\mathrm{P} \times \mathrm{ts}]\right]$

$+3 \mathrm{~S}$

+ part

$\left\{\begin{array}{c}\text { +sein } \\ \text { +pass } \\ + \text { refl }\end{array}\right\}$

(RESULT $\in<\mathrm{e},<\mathrm{e}, \mathrm{t}>>$ )

The input to this rule are participles II with the marking $+3 \mathrm{~S}+$ part, which in addition have the feature + sein or have undergone passivization or belong to the class of verbs with the morphosyntactic feature +refl (like sich rasieren, sich verändern, sich verspäten, sich betrinken etc.).

Semantically, the rule of conversion characterizes the highest participant as being in a result state of the underlying verb. I assume that a meaning postulate makes explicit that the resulting situation s' instantiates the proposition which in the semantic representation of the verb identifies the goal state (for instance, [OFFEN x] in the case of geöffnet as the converted adjective of öffnen or of sich öffnen).

\subsection{The copula}

Adjectival phrases are one-place predicates and can combine with the copula, which - like all lexical verbs - comes with a situation argument $s$ and a temporal argument $t$.

(12) The copula
a. /sein/,
$10 /$
b. $+\mathrm{V}-\mathrm{N}$
c. $\lambda P \lambda x \lambda t \lambda s\left[\left[T s \underline{R}_{a p p} t\right] \&[\right.$ INST P $\left.x]\right]$

By assuming the existence of a silent copula one can explain the far-reaching parallelism of participial modifiers and modifiers with an embedded adjective phrase. For instance, consider cases like (13) and (14).

(13) der seit zwei Wochen $\emptyset_{\text {cop }}$ kranke Nachbar the since two weeks ill neighbour

'the neighbour who has been ill for two weeks'

der seit zwei Wochen $\emptyset_{\text {cop }}$ verreiste Nachbar the since two weeks away neighbour 'the neighbour who has been away for two weeks' 
(14) der krank gewesene cop Nachbar

the ill been neighbour

'the neighbour who has/had been ill'

der verreist gewesene $e_{\text {cop }}$ Nachbar

the away been neighbour

'the neighbour who has/had been away'

In (13), the adverbial seit zwei Wochen relates to the time interval provided by the silent copula. In (14), the explicit perfect form gewesen of the copula furnishes the modifier construction with perfect semantics, more precisely with the preterite-like before-relation. In order to avoid unnecessary syntactic effort, I propose to combine adjectival modifiers with the copula only if the situation argument or the temporal argument have to be considered.

\subsection{Participial modifiers as reduced sentences}

Adjectival and participial modifiers are considered as reduced sentences. They do not provide a syntactic position for the subject or for an operator (comparable to the relative pronoun in relative clauses) or for an adverbial relator (as in adverbial clauses). ${ }^{4}$ The pertinent components are present only in the semantic structure. The functional projections ForceP, MoodP and TenseP are absent.

I assume that adjectival modifiers without the copula have the SF schema (15), whereas participial modifiers including adjectival phrases enriched by the copula have the SF schema (16a) or (16b).

(15) SF schema for adjectival modifiers

$\lambda \times[\ldots \times \ldots]$

(16) SF schemata for participial modifiers

(a) Attributive modifiers

$$
\lambda x \exists s \exists t[\ldots s . . . t \ldots x \ldots]
$$

(b) Adverbial modifiers

$$
\begin{aligned}
& \lambda s^{\prime} \exists s \exists t\left[\left[s^{\prime} R_{a d y} s\right] \&[\ldots s \ldots t \ldots x \ldots]\right] \\
& \left.\left(\mathrm{R}_{\mathrm{adv}} \in\langle\mathrm{e},<\mathrm{e}, \mathrm{t}\rangle\right\rangle\right)
\end{aligned}
$$

Thus it is necessary to convert participle constructions to the schemata in (16) so that they can function as one-place modifiers. Again, there are two possibilities: the affixless method or the method of zero-affixation. My preference is clear. But this time, I would like to leave open the possibility of having the modifier construction undergo a category change: either to adjectival or to prepositional phrases. I indicate these conversions in (17b) and (18b). I believe there is some evidence for these conversions. Firstly, attributive participle constructions come up with adjectival inflection (see (1)-(3)). Secondly, the adverbial meaning in (18c) - though very abstract - is comparable with that of adverbial conjunctions such as bis, seit, während etc., which I would categorize as -V-N entities. ${ }^{5}$

4 Compare the analysis of adjectival and participial modifiers by Fanselow (1986).

5 For the status of adverbial conjunctions see Steube (1987). 
(17) Conversion to adjectival modifiers (ADJ)
(a. $/ \varnothing /$ )
(b. $+\mathrm{V}+\mathrm{N})$
c. $\lambda \mathrm{P} \quad \lambda \times \exists \mathrm{s} \exists \mathrm{t}[\mathrm{P} \times \mathrm{ts}]$
+ MAX
$+3 \mathrm{~S}$
tpart
$\left\{\begin{array}{c}\text { +sein } \\ + \text { pass } \\ + \text { refl }\end{array}\right\}$

(18) Conversion to adverbial modifiers (ADV)
(a. $/ \varnothing /)$
(b. - V-N)
c. $\lambda P \quad \lambda s^{\prime} \exists s \exists t\left[\left[s^{\prime} \underline{R}_{a d v} s\right] \&[P \times t s]\right]$ + MAX
$+3 \mathrm{~S}$
+part
$\left\{\begin{array}{c}\text { tsein } \\ + \text { pass } \\ \text { trefl }\end{array}\right\}$

As in the case of conversion of participles to adjectives, the two rules apply to constituents marked by the features $+3 \mathrm{~S}+$ part and +sein or +pass or +refl, respectively. ${ }^{6}$ The rules are restricted to maximal projections (+MAX). (17) equips us with modifiers relating to partici-

6 The question in which cases participles II as heads of modifiers relate to reflexive verbs deserves special attention. In contexts like (i), the participle does not seem to correspond to the reflexive verb sich öffnen. It can be understood as passive of the verb offnen or as the converted adjective.

(i) das gestern geöffnete Fenster

the yesterday opened window

'the window that was opened yesterday'

But in (ii) the participles could also be related to the pertinent reflexive verbs.

(ii) die geöffneten Blüten

'the open blossoms'

cf. die Blüten haben sich geöffnet

der verspätete Eilzug

'the delayed express train'

cf. der Eilzug hat sich verspätet

'the drunken porter'

cf. der Pförtner hat sich betrunken

In many cases, as in (iii), the participle is ambiguous between being an adjective and being derived from the corresponding transitive or reflexive verb.

(iii) Die Frau fühlte sich, in eine warme Decke gehüllt, wieder wohler.

the woman felt, in a warm blanket wrapped, again better

'Wrapped in a warm blanket, the woman felt better again.'

Die in eine warme Decke gehüllte Frau fühlte sich wieder wohler.

the in a warm blanket wrapped woman felt again better

'The woman who was wrapped in a warm blanket felt better again.'

Therefore, among various possibilities I have made the applicability of the three conversions CONV, ADJ, ADV depend on the presence of the morphosyntactic feature + refl in the MSC of the participle. 
pants, (18) with those relating to situations. In both cases, the situation argument and the temporal argument of the underlying verb are existentially bound. In addition, (18) blocks the highest participant argument $\mathrm{x}$ of the verb. This variable can be regarded as a parameter involved in control relations (Haspelmath 1995). The relational parameter $R_{\mathrm{adv}}$ in (18c) leaves room for context-dependent specification of the pertinent adverbial relation between two situations in Conceptual Structure (König 1995).

\subsection{The semantic integration of modifiers}

There are four types of modifiers I wish to distinguish: intersective modifiers, appositive modifiers, secondary predicates ${ }^{7}$ and operator-like modifiers. On their own all modifiers, according to the conception proposed here - are one-place predicates. Thus, the differentiation mentioned above must reside in the mode of combining the modifying predicates with the modificandum. Here I will concentrate on intersective modification and on operator-like modification, MOD1 and MOD2.

(19) Modification template MOD 1

$\lambda \mathrm{Q} \lambda \mathrm{P} \lambda \mathrm{x}[\mathrm{P} \mathrm{P}] \&[\mathrm{Q} \times]]$

$(\mathrm{P}, \mathrm{Q} \in<\mathrm{e}, \mathrm{t}>)$

(20) Modification template MOD 2

$\lambda \mathrm{Q} \lambda \mathrm{p}[[\mathrm{Q} \times] \mathrm{C} \mathrm{p}]$

$(\mathrm{Q} \in<\mathrm{e}, \mathrm{t}, \mathrm{C} \in<\mathrm{t},<\mathrm{t}, \mathrm{t}>)$

Both templates operate on one-place predicates and enrich them by adding a position for the modificandum. ${ }^{8}$ Furthermore, (19) unifies the highest arguments of the modifier and the modificandum." The two propositions are combined by $\&$. (20) leaves the nature of the connector unspecified. $\mathrm{C}$ is a parameter. The modificandum in (20) is a proposition and the highest argument position $\mathrm{x}$ of the modifier is blocked. This variable, too, is a parameter, which can take part in relations of co-reference. With (20) we get frame setting modifiers which specify conditions for the pertinent proposition of the modificandum to be valid.

I believe the template in (19) integrates the intersective modifiers of the examples (1)(4), whereas (20) characterizes the modifiers in (5)-(6) as propositional operators.

\subsection{Examples}

Having commented on the basic components of my analysis I would like to add three examples with participial modifiers which have undergone the proposed operations of morphological, syntactic, and semantic structuring.

7 See Koch/Rosengren (1995) and Kaufmann/Wunderlich (1998).

8 Compare the assumptions of Wunderlich (1997b), who proposes enriching the argument structure of the modificandum in order to integrate a modifier.

9 Possibly, we need a more general schema of intersective modification unifying several arguments of the modifier and of the modificandum at once (Jacobs 1995). Moreover, it seems necessary that various arguments of the modificandum are allowed to be unified with the highest arguments of the modifier. The schema (i) should replace MOD1.

(i) $\lambda Q \lambda \mathrm{P} \lambda \underline{\underline{z}} \ldots[[\mathrm{P} \underline{\underline{z}} \ldots] \&[Q \underline{\underline{z}}]$

$(\mathrm{Q} \in<\alpha, \mathrm{D}, \mathrm{P} \in<\beta, \mathrm{t}, \lambda \underline{\underline{z}}, \underline{\underline{z}}-\mathrm{n}$ lamda operators and variables $(\mathrm{n} \geq 1))$ 
(21) das [von allen geliebte] Kind ${ }^{10}$

the by everybody loved child

'the child that is/was loved by everybody'

MOD 1 (ADJ (MOD1 (von allen')(Pass (VP'))))

ty [[ CHILD y ] \& $\exists \mathrm{s} \exists \mathrm{t}\left[\left[\exists \mathrm{x}\left[\left[\right.\right.\right.\right.$ Ts $\left.\underline{R}_{\text {asp }} \mathrm{t}\right] \&[\mathrm{~s}$ INST $\mathrm{x}$ LOVE y ]]] \&

$\left.\left.\forall \mathrm{z}\left[[\underline{\mathrm{P} z}] \rightarrow\left[\mathrm{z} \underline{\mathrm{R}}_{\mathrm{th}} \mathrm{s}\right]\right]\right]\right]$

(22) [Geleert] fuhren die Wagen ins Depot.

unloaded went the lorries to the depot

'After having been unloaded, the lorries went to the depot.'

MOD 1 (ADV (PERF (PASS (VP'))))

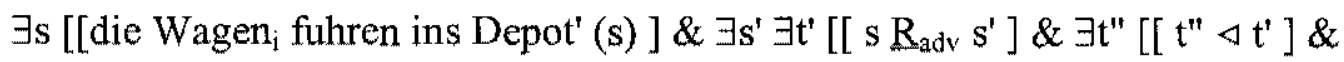

$\exists x\left[\left[\mathrm{Ts}^{\prime} \underline{\mathrm{R}}_{\mathrm{asp}} \mathrm{t}\right.\right.$ " ] \& [ s' INST x DO-CAUSE BECOME EMPTY $\left.\left.\left.\left.\left.\mathrm{y}_{\mathrm{i}}\right]\right]\right]\right]\right]$

(23) [Verwelkt] kaufe ich die Rose nicht.

faded buy I the rose not

'Faded as it is I will not buy the rose.'

MOD 2 (CONV (VP'))

$\exists s^{\prime} \exists s \exists t$ [[ s' RESULT $\left.s\right]$ ] [[ Ts $\left.\mathrm{R}_{\underline{\underline{a s p}}} \mathrm{t}\right]$ \& [ s INST BECOME WELK $\left.\left.\left.\mathrm{x}_{i}\right]\right]\right] \mathrm{C}$ [ ich kaufe die Rose; nicht']

Co-reference is represented by indices. The SF of the modifiers results from the operations indicated. The SF of the matrix constructions in (22) and (23) is not laid out in detail. As to their nature, the participles in (22) and (23) contrast heavily. Geleert in (22) functions as intersective modifier relating to situations. Verwelkt in (23) functions as operator-like modifier and relates to a proposition. Geliebt in (21) is an intersective modifier.

\section{Summary}

This article is concerned with the interaction of morphology, syntax and semantics. It deals with German past participles and concentrates on their function in attributive, adverbial and operator-like modifier phrases.

The proposed analysis shows that the high degree of semantic underspecification and interpretative flexibility of German participial modifiers resides in the indeterminacy of past participles with respect to voice and perfect, in the absence of certain constituents in the syntactic structure of modifiers and in the presence of corresponding parameters in the Semantic Form of participle phrases.

It is presupposed that syntactically, modifiers are adjuncts. As to their internal syntax, participial modifiers are regarded as reduced sentences without a syntactic position for the grammatical subject, for an operator comparable to relative pronouns or for an adverbial relator as in adverbial clauses and without tense and mood (Wunderlich 1987). 
The morphosyntactic features +pass, + perf of the past participle are checked in syntax by being interpreted semantically. Whether these operations are connected with phonetically empty functional heads or are simply devices of delayed semantic interpretation of morphosyntactic features is left open to consideration.

It can be assumed that there are three conversions. One of them equips us with adjectives with resultative meaning. The two other conversions interpret participle phrases as adjectival or adverbial modifiers respectively.

I assume two templates that concern the composition of participle constructions as modifiers with the modificandum. One of them accounts for intersective modification, the other for operator-like modification. Appositive modifiers, parentheses and secondary predicates are left out of consideration.

The analysis follows minimalist principles of sound-meaning correlation and tries to avoid unnecessary syntactic structures. Much work is left to Conceptual Structure. The Semantic Form of linguistic expressions in general, and of German participle II constructions in particular, is highly underdetermined. It has been shown that various parameters leave the SF of German participle II phrases highly unspecified.

Finally, I would like to mention that my analysis of German participial modifiers is guided and influenced by having in mind the rich system of participles and adverbial participles in Russian. Morphologically, these are far more differentiated and semantically, these are far less unspecified.

\section{References}

Anagnostopoulou, Elena, Iatridou, Sabine, Izvorski, Roumyana (1998): On the Morpho-Syntax of the Perfect and How it Relates to its Meaning. - Manuskript.

van der Auwera, Johan (ed.) (1998): Adverbial Constructions in the Languages of Europe. - Berlin, New York Mouton de Gruyter (= Empirical Approaches to Language Typology 2O, EUROTYP 3).

Bayer, Josef, Römer, Christine (Hgg.)(2000): Von der Philologie zur Grammatiktheorie. - Tübingen: Niemeyer.

Bech, Gunnar (1955/1957): Studien über das deutsche verbum infinitum. - Kobenhavn (1. Bd. 1955, 2.Bd.1957): Munksgaard.

Benedicto, Elena E., Runner, Jeffrey 'T. (eds.)(1994): Functional Projections. - University of Massachusetts Occasional Papers (UMOP) 17. Graduate Linguistic Student Association (G.L.S.A.) Amberst, Univerity of Massachusetts.

Bierwisch, Manfred (1987): Semantik der Graduierung. - In: M. Bierwisch, E. Lang (Hgg.), 91-286.

-.. (1990): Verb Cluster Formation as a Morphological Process. - In: G. Booij, J. van Marle (eds.), 173-190.

- (1997a): Lexical Information from a Minimalist Point of View. - In: Ch. Wilder, H.-M. Gärtner, M. Bierwisch (eds.), 227-266.

(1997b): Probleme der Kompositionalität des deutschen Tempussystems. - Handout.

Bierwisch, Manfred, Lang, Ewald (Hgg.)(1987): Grammatische und konzeptuelle Aspekte von Dimensionsadjektiven. - Berlin: Akademie-Verlag (= Studia grammatica 26/27).

Bierwisch, Manfred, Motsch, Wolfgang, Zinmermann, Ilse (Hgg.)(1988): Syntax, Semantik und Lexikon. Berlin: Akademie-Verlag (= Studia grammatica 29).

Booij, Geert, van Marle, Jaap (eds.)(1990): Yearbook of Morphology. - Dordrecht: Foris.

Dernjjanow, Assinja (1998): Eine semantische Analyse der Perfektivierungspräfigierung im Russischen. Dissertation, Humboldt-Universität Berlin, erschienen in München: Sagner (Slavistische Beiträge 365).

Dölling, Johannes (1997): Semantic Form and Abductive Fixation of Parameters. - In: R. van der Sandt, R. Blutner, M. Bierwisch (eds.), 113-139.

- (1998): Das Partizip II und seine 'Bedeutungen': Ereignisse, Zustände, Zeiten. - Arbeitsmaterial vom 8. und 16.4.1998, Handout vom 24.4.1998.

Fanselow, Gisbert (1986): On the Sentential Nature of Prenominal Adjectives in German. - In: Folia Linguistica 20. 3-4, 341-380.

Frey, Werner, Pittner Karin (1998): Zur Positionierung der Adverbiale im deutschen Mittelfeld. - Linguistische Berichte 176n, 489-534.

Grundzüge (1981): Grundzüge einer deutschen Grammatik. Von einem Autorenkollektiv unter der Leitung von Karl Erich Heidolph, Walter Flämig, Wolfgang Motsch. - Berlin: Akademie-Verlag. 
Haider, Hubert (1999): Adverb Placement - Convergence of Structure and Licensing. - Manuskript.

-.- / Rosengren, Inger (1998): Scrambling. - Sprache und Pragmatik 49. Arbeitsberichte, Lund.

Haspelmath, Martin (1995): The Converb as a Crosslinguistically Valid Category. - In: M. Haspelmath, E. König (eds.), 1-55.

Haspelmath, Martin, König, Ekkehard (eds.)(1995): Converbs in Cross-Linguistic Perspective. Structure and Meaning of Adverbial Verb Forms - Adverbial Participles, Gerunds. - Berlin, New York: Mouton de Gruyter (= Empirical Approaches to Language Typology 13).

Hengeveld, Kees (1998): Adverbial Clauses in the Languages of Europe. - In: J. van der Auwera (ed.), 335-419.

Jacobs, Joachim (1995): Wieviel Syntax braucht die Semantik? Möglichkeiten und Grenzen einer sparsamen Theorie der Bedeutungskomposition. - Theorie des Lexikons. Arbeiten des Sonderforschungsbereichs 282, Nt. 73. Düsseldorf: Heinrich-Heine-Universität.

Kaufmann, Ingrid, Wunderlich, Dieter (1998): Cross-Linguistic Patterns of Resultatives. - Theorie des Lexikons. Arbeiten des Sonderforschungsbereichs 282, Nr. 109. Düsseldorf: Heinrich-Heine-Universität.

Klein, Wolfgang (1994): Time in Language. - London, New York: Routledge.

(.... (1995): A Time-Relational Analysis of Russian Aspect. - In: Language 71. 4, 669-685.

- (1999): Wie sich das deutsche Perfekt zusammensetzt. - In: Zeitschrift für Literaturwissenschaft und Linguistik 29, H. 113, 52-85.

Klein, Wolfgang, Vater, Heinz (1998): The Perfect in English and German. - In: L. Kulikov, H. Vater (eds.), $215-235$.

Koch, Wolfgang, Rosengren, Inger (1995): Secondary Predications: Their Grammatical and Conceptual Structure. - Sprache und Pragmatik 35. Arbeitsberichte, Lund.

König, Ekkehard (1995): The Meaning of Converb Constructions. - In: M. Haspelmath, E. König (eds.), 57-95.

Kortmann, Bernd (1995): Adverbial Participial Clauses in English. - In: M. Haspelmath, E. König (eds.), 189237.

Kratzer, Angelika (1994a): On External Arguments. - In: E. E. Benedicto, J. T. Runner (eds.), 103*130 (= Kap. 1 in A. Kratzer (1994b).

- (1994b): The Event Argument and the Semantics of Voice. - Manuskript.

- (1998): Aspect in Adjectival Passives. - Handout, WCCFL XVII, University of British Columbia, February 20-22, 1998

Kulikov, Leonid, Vater, Heinz (eds.)(1998): Typology of Verbal Categories. Papers Presented to Vladimir Nedjalkov on the Occasion of His 70th Birthday. - Tübingen: Niemeyer ( $=$ Linguistische Arbeiten 382).

Lang, Ewald (1987): Semantik der Dimensionsauszeichnung räumlicher Objekte. - In: M. Bierwisch, E. Lang (Hgg.), 287-458.

- (1990): Sprachkenntnis, Objektwissen und räumliches Schließen. - In: Zeitschrift für Literaturwissenschaft und Linguistik 78, 59-97.

- (1994): Semantische und konzeptuelle Struktur: Üterscheidung und Überschneidung. - In: M. Schwarz (Hg.), 25-40.

Lenz, Barbara (1993): Probleme der Kategorisierung deutscher Partizipien. - In: Zeitschrift für Sprachwissenschaft 12.1,39-76.

- (1995): Un-Affigierung. Unrealisierbare Argumente, unausweichliche Fragen, nicht unplausible Antworten. Tübingen: Narr $(=$ Studien zur deutschen Grammatik 50).

- (1996): Sein, bleiben und werden im Negations- und Partizipial-Kontext. - In: Linguistische Berichte 162, 161-182.

Maienborn, Claudia (1996): Situation und Lokation. Die Bedeutungg lokaler Adjunkte von Verbalprojektionen. Tübingen: Stauffenburg Verlag (= Studien zur deutschen Grammatik 53).

- (1997): On the Meaning of Sentence Modifiers: Semantic Indeterminacy and its Grammatically Induced Specification. - In: R. van der Sandt, R. Blutner, M. Bierwisch (eds.), 183-202.

- (1998): The Grammar and Pragmatics of Locative Modifiers. - Manuskript.

Motsch, Wolfgang (ed.)(1988): The Contribution of Word-Structure Theories to the Study of Word Formation. Berlin (- LS/ZISW/A 179).

Musan, Renate (1998): The Core Semantics of the Present Perfect. - In: ZAS Papers in Linguistics 10, 113-145.

- (1999): Die Lesarten des Perfekts. - In: Zeitschrift für Literaturwissenschaft und Linguistik 29, H. 113, 651.

Nedjalkov, Igor' V. (1995): Converbs in Evenki. - In: M. Haspelmath, E. König (eds.), 441-463.

- (1998); Converbs in the Languages of Europe. - In: J. van der Auwera (ed.), 421-455.

Nedjalkov, Vladimir P. (1995): Some Typological Parameters of Converbs. - In: M. Haspelmath, E. König (eds.), 97-136.

Rapp, Irene (1996): Zustand? Passiv? - Überlegungen zum sogenannten „Zustandspassiv“. - In: Zeitschrift für Sprachwissenschaft 15.2, 231-265.

(1997); Partizipien und semantische Struktur. Zu passivischen Konstruktionen mit dem 3. Status. Tübingen: Stauffenburg Verlag (= Studien zur deutschen Grammatik 54). 
Růžička, Rudolf (1978): Erkundungen für eine Typologie der syntaktischen und semantischen Strukturen der Gerundien. (Adverbialpartizipien) in modernen slawischen Literatursprachen. - In: Zeitschrift für Slawistik 20. 2, 229-244.

- (1982): Kontrollprinzipien infiniter Satzformen: Infinitiv und Gerundium (deepricastie) im Russischen und in anderen slawischen Sprachen. - In: Zeitschrift für Slawistik 27.3, 373-411.

van der Sandt, Rob, Blutner, Reinhard, Bierwisch, Manfred (eds.)(1997): From Underspecification to Interpretation - Working Papers of the Institute for Logic and Linguistics. IBM Deutschland, Heidelberg.

Schwarz, Monika (Hg.)(1994): Kognitive Semantik: Ergebnisse, Probleme, Perspektiven. - Tübingen: Narr (= Tübinger Beiträge zur Linguistik 395).

von Stechow, Arnim (1998): Participles II in German. - Handout.

- (1999a): Eine erweiterte extended now - Theorie für Perfekt und Futur. - In: Zeitschrift für Literaturwissenschaft und Linguistik 113, 86-118.

- (1999b): Semantics and Syntax of Perfect and Future. - LOT Sommer School, University of Potsdam, July 19-21, 1999.

Steube, Anita (1987): Grammatical relations between prepositions, conjunctions and the complementizer ,daá“ in a REST-grammar of German. - In: Linguistische Arbeitsberichte 61, Leipzig, 54 74.

Toman, Jindřich (1986): A (Word) Syntax for Participles. - In: Linguistische Berichte 105, 367-408.

Wilder, Chris, Gärtner, Hans-Martin, Bierwisch, Manfred (eds.)(1997): The Role of Economy Principles in Linguistic Theory. - Berlin: Akademie Verlag GmbH (= Studia grammatica 40).

Wunderlich, Dieter (1987): Partizipien im Deutschen.* In: Linguistische Berichte 111, 345-366.

- (1997a): Participle, Perfect and Passive in German. - Theorie des Lexikons. Arbeiten des Sonderforschungsbereichs 282, Nr. 99. Düsseldorf: Heinrich-Heine-Universität.

- $\quad$ (1997b): Argument Extension by Lexical Adjunction. - In: Journal of Semantics 14, 95-142.

- (1997c): A Minimalist Model of Inflectional Morphology. In: Ch. Wilder, H.-M. Gärtner, M. Bierwisch (eds.), 267-298.

Zimmermann, Ilse (1985): Der syntaktische Parallelismus verbaler und adjektivischer Konstruktionen (Zu einigen Grundfragen der X'-Theorie). - In: LS/ZISW/A 127, Berlin, 159-213.

- (1987): Zur Syntax von Komparationskonstruktionen. - In: M. Bierwisch, E. Lang (Hgg.), 13-69.

- $\quad$ (1988a): Wohin mit den Affixen? - In; W. Motsch (ed.), 157-188.

- (1988b): Die substantivische Verwendung von Adjektiven und Partizipien. - In: M. Bierwisch, W. Motsch, I. Zimmermann (Hgg.), 279-311.

- (1992): Der Skopus von Modifikatoren. - In: I. Zimmermann, A. Strigin (Hgg.), 251-279.

- (1999): Partizip II - Konstruktionen des Deutschen als Modifikatoren. - In: ZAS Papers in Linguistics 14, 123-146. Also in: J. Bayer, Ch. Römer (Hgg.), 239-269.

- (2000): Die eingeschränkte Satzartigkeit modifikatorischer Partizip II - Konstruktionen. In: Linguistische Arbeitsberichte 74, Leipzig, 249-269.

/ Strigin, Anatoli (Hgg.)(1992): Fügungspotenzen. Zum 60. Geburtstag von Manfred Bierwisch. - Berlin: Akademie Verlag (= Studia grammatica 34 ). 